\title{
Economic Migration of Eastern Europeans in the UK after the UK Referendum Held in 2016
}

\author{
Magdalena Kotýnková1,* \\ ${ }^{1}$ University of Economics Prague, Department of Economics and Social Policy, W. Churchill Sq. 4, \\ 13067 Prague 3, Czech Republic
}

\begin{abstract}
The economic status of Eastern European migrants has become a major issue in the UK, as it was one of the main arguments for leaving the European Union in the 2016 Referendum. The negative view on migrants from Eastern Europe in the UK relies on the fact that these migrants are a major burden for the British social and healthcare system. At the same time, however, the issue of modern slavery is discussed, based on the fact that Eastern Europeans in the UK are willing to work under undignified working conditions. The aim of the paper is to analyse and evaluate the economic status of Eastern Europeans on the UK labour market. The paper is based on the theoretical concept of the dual labour market, which is used in the analysis of real data. The dataset used was prepared by the UK Office for National Statistics (GB): As the conclusion, the expected changes in migration of the Eastern Europeans after the UK's leaving the European Union, currently scheduled for 31 November 2020, are given.
\end{abstract}

\section{Introduction}

The status of East European migrants in the UK is a very topical issue, given the outcome of the UK referendum held in 2016, where the main argument for leaving the European Union (hereinafter: EU) was the large immigration from Eastern Europe. Official figures show that net migration from the Eastern European countries which joined the European Union in 2004 rose sharply following the accession and peaked in 2007. Net migration from Romania and Bulgaria, states which joined the EU in 2007 increased sharply from 2014 onwards, which was likely augmented by the ending of UK transitional controls on migration from those countries in January 2014.

The rise in net migration from Eastern Europe has likely been driven in large part by the fact that wages available in the UK are considerably higher than in countries of origin. For example the minimum wage in the UK, between 2010 and 2018, was over three times higher than in Poland [1]. The Polish diaspora is the largest diaspora in the UK. The rise in the Polish-born population has more than tripled in size between 2007 to 2018, even though the number of Polish migrants began to decline after the 2016 Referendum. Also notable is the rise in the Romanian-born community over the same period. The Czech-born population

\footnotetext{
*Corresponding author: kotynkov@vse.cz
} 
is not significant in size, but Roma population born in the Czech Republic along with Roma population born in Slovakia living in the UK is mainly gathered in socially excluded areas.

In today's increasingly interconnected world, migration has become a reality. Modern transportation has made it easier, cheaper and faster for people to move in search of jobs, opportunity, education and quality of life. Migration can contribute to sustainable economic growth both home and host countries. Countries of destination benefit from migration as migrants fill labour gaps and pay taxes and social security contributions. Some of migrants are among members of the communities that contribute to the development of science and technology in host countries [2]. A part of migrants, including Eastern European migrants are sending home remittances that supplement household income and improve the livelihoods of families.

However, inequality and poverty compel people to leave their homes to seek a better future for themselves and their families abroad and many Eastern European migrants remain among the most vulnerable workers in host countries. Migrants are often the first to lose their jobs in the event of an economic downturn, they work for less pay, for longer hours, and in worse conditions than native-born workers [3]. The aim of the paper is to build up a picture of how national populations in the UK are changing due to the movement of people around the Europe and especially analyse and evaluate the economic status of Eastern European migrants in the UK society.

\section{Material and Methods}

Understanding migration statistics requires an explanation of the terminology used. The first issue need to be discussed is: who is a migrant? A migrant is broadly defined as a person who changes their country of residence. Conventionally, there are two different ways of making this definition more precise [4]:

- A migrant is someone whose country of birth is different to their country of residence.

That definition is consistent and objective, includes people born abroad but classifies as migrants also people who were born abroad but who are nevertheless nationals of the country in which they live: e.g. children born to armed forces personnel stationed in foreign countries.

- A migrant is someone whose nationality is different to their country of residence. That definition includes nationals born abroad but excludes people who have changed their country of residence and acquired the nationality of their new home country.

The second issue need to be discussed is: what is the difference between migrant stocks and flows? In migration statistics, stocks refer to the number of migrants resident i.e. people whose country of birth or nationality is different from that of the country in which they live during a particular period. Flows refer to the number of people changing their country of residence during a particular period. Stocks and flows are normally measured as the number of people changing the country of residence for a period of at least a year. Net migration is the measure of the net flow of migrants into and out of a country, it means the difference between immigration and emigration: the number of people moving to live in a particular country minus the number of people moving out of that country to live elsewhere The datasets used were prepared by the UK Office for National Statistics: Population of the UK by country of birth and nationality [5,6] and dataset Labour Force Survey [7].

From a methodological perspective on labour market position of migrants, the concept of the dual labour market is used in this paper. The dual labour market concept was worked out by the American economist M. J. Priore [8]. The labour market is divided into primary and secondary sectors: 
- Workplaces created in the primary sector of the labour market distinguish themselves by high protection of workplaces, possibilities of a future carrier development and good working conditions. They provide high wages, extra bonuses, possibility of trainings and bigger chances in the labour market in the case of a job loss.

- Workplaces created in the secondary sector of the labour market are unsecured, have worse working conditions, lower work and legal protection of employees, poorer wage prospects, low possibility of personal development and also repetitive and long-term unemployment. In the secondary labour market there are mainly disadvantaged groups of workers including migrants.

\section{Results and Discussion}

\subsection{Migrants net migration in UK}

Building up a picture of how population are changing due to the movement of migrants means take into account net migration, i.e. the net flow of migrants into and out of a country. The number of people migrating to the UK has been greater than the number emigrating since 1994. However, for much of the twentieth century, the numbers migrating to and from the UK were roughly in balance, and from the 1960s to the early 1990s the number of emigrants was often greater than the number of immigrants. Over the last twenty five years, both immigration and emigration have increased to historically high levels, with immigration exceeding emigration by more than 100,000 in every year since 1998, see figure 1.

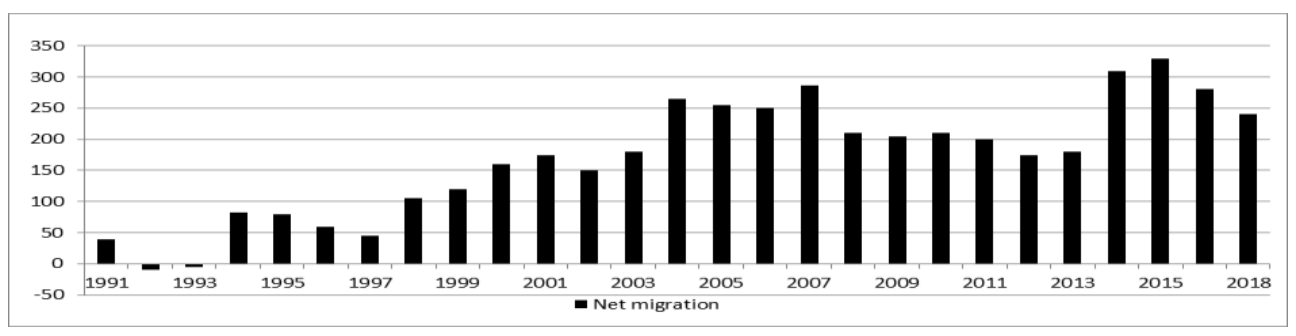

Fig. 1. Net international migration in the UK by country of birth, 1991 - 2018

Source: Office for National Statistics (GB)

Immigration in the UK has grown faster than emigration since 1998, leading to an increase in net migration from an annual average of 37,000 in the period 1991 to 1995 to an annual average of 253,000 in the period 2012 to 2017 . Net migration has risen sharply form 2004, when the Eastern European countries joined the EU and peaked in 2007. The next sharp increase in net migration was recorded in 2014 - 2015, which was likely due to the end of the UK's transitional controls on migration from Romania and Bulgaria in January 2014. Romania and Bulgaria joined the EU in 2007. The position of Eastern European migrants in the UK society has become a very topical issue, given the outcome of the 2016 Referendum, where the main argument for leaving the EU (Brexit) was a large immigration from Eastern Europe.

\subsection{From which countries do people migrate to the UK?}

In $2018,14.3 \%$ of the UK population were international migrants, out of which $5.6 \%$ were EU-immigrants and $8.7 \%$ came from non-EU countries, i.e. from European non-EU countries and non-European countries. The large number of migrants from EU countries 
were born in the EU14 $4^{\dagger}(48 \%)$, followed by immigrants born in the EU8* $(36.7 \%)$. The smaller number of immigrants from EU countries were born in the EU2 $\$$ (13.6\%) and in the EU other countries ${ }^{* *}(2.5 \%)$. Almost $90 \%$ of migrants from EU2 (88 \%), EU8 (87\%) and European non-EU countries (88\%) are at aged $16-64$ (i.e. at working age) which is the highest level of all geographical groups.

The largest group of migrants in the UK $(832,000)$ was born in Poland, followed by migrants from India and Pakistan. A large group of migrants was also born in Romania (390,000), ranked fourth.

Table 1. Migrant stock in the UK by country of birth, January 2018 to December 2018

\begin{tabular}{|l|l|c|}
\hline $\begin{array}{l}\text { List of the first five countries plus the } \\
\text { placement of other EU8 and EU2 countries }\end{array}$ & \multicolumn{1}{|c|}{ Country of birth } & $\begin{array}{c}\text { Migrants stock } \\
\text { in thousands }\end{array}$ \\
\hline 1 & Poland & 832 \\
\hline 2 & India & 831 \\
\hline 3 & Pakistan & 535 \\
\hline 4 & Romania & 392 \\
\hline 5 & Republic of Ireland & 369 \\
\hline
\end{tabular}

Note: Estimated numbers of migrants are measured through the Labour Force Survey (LFS) and the Annual Population Survey (APS), which aggregates and supplements LFS data.

Source: Office for National Statistics (GB)

However, the number of Polish migrants decreased significantly in 2018, as did the number of migrants from other Visegrad4 countries (i.e. Hungary, Slovakia and the Czech Republic) and from Latvia. On the other hand, the number of migrants from Romania, Bulgaria and Lithuania continued to grow in 2018. The migrants group from the Czech Republic was relatively small $(45,000)$ in 2018 (ranked 47rd place of 60 countries), see figure 2.

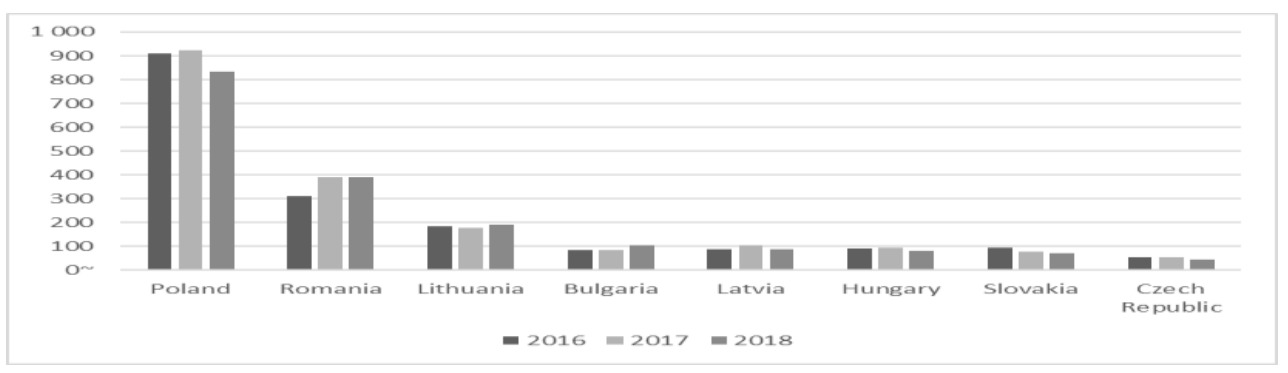

Fig. 2. EU8 migrant stock in the UK by country of birth in $2016-2018$.

Note 1: Estimated numbers of immigrants are measured through the Labour Force Survey (LFS) and the Annual Population Survey (APS), which aggregates and supplements LFS data.

Note 2: Slovenia and Estonia is not included due to migrants stock from these 2 countries in UK is not significant

Source: Office for National Statistics (GB)

\footnotetext{
$\dagger$ EU14 consists of old member state countries, UK is not included in this grouping because is shown separately.

${ }^{\ddagger}$ EU8 consists of the Eastern European countries that joined the EU in 2004: Czech Republic, Estonia, Poland,

Hungary, Latvia, Lithuania, Slovakia and Slovenia.

${ }^{\S}$ EU2 consists of the two countries that joined the EU in 2007: Bulgaria and Romania.

*** EU other countries consist of Malta and Cyprus joint EU in 2004 and Croatia joined EU in 2013
} 
Net migration from the EU8 rose sharply following the accession of those countries into the EU in 2004 and was 137,000 at its peak in 2007, but has began stagnated after the 2016 Referendum and decreased in 2018. Net migration from E2, countries which joined the EU in 2007, increased from 2014 onwards, more than doubled from 21,000 in the year 2013 to 64,000 in 2018. This increase was likely augmented by the ending of UK transitional controls on migration from those countries in January 2014 [9].

\subsection{Why do people from Eastern Europe migrate to the UK?}

Strong incentives for migration from East European countries include a much higher wages in the UK relative to the countries of Eastern Europe, the pull effect of migrants already living in the UK and political turbulence in Eastern Europe:

- The rise in net migration from Eastern Europe has likely been driven in large part by the fact that wages available in the UK are considerably higher than in countries of origin. The minimum wage in the UK, between 2010 and 2018, was over three times higher than in Poland. The UK's 2018 minimum wage (1397 Euros per month) remains three times higher than Poland's minimum wage (453 Euros per month) and is five times higher than Romania's minimum wage (275 Euros per month) [1].

- Kinship and growing existing communities of EU8 and EU2 nationals in the UK act as a draw for migration. The 2018 figure includes more than 1.3 million people born in the EU8 and nearly 5 hundred thousand born in the EU2, see table 1.

- Political turbulence in Eastern Europe could act as a push factor for potential migrants to other parts of Europe including EU. For example Poland's ruling Law and Justice Party has been accused of pursuing a polarising agenda, a factor which may has driven opponents of the government to seek residence elsewhere in the EU.

\subsection{East European migrants in the UK labour market}

A key indicator of labour market outcomes is the employment rate measuring the share of the employed in the total working-age population. In 2018 the employment rates of male workers from the Europe, i.e. EU2 (92\%), EU8 (91\%) and EU14 (83\%) were higher than those of UK-born men (79\%). The employment rates of female workers from EU2 (76\%) and EU8 (75\%) countries were higher than employment rate of UK-born women (72\%). However, the employment rate of women from EU14 (69\%) was less that of UK-born women $(72 \%)$, see figure 3 .

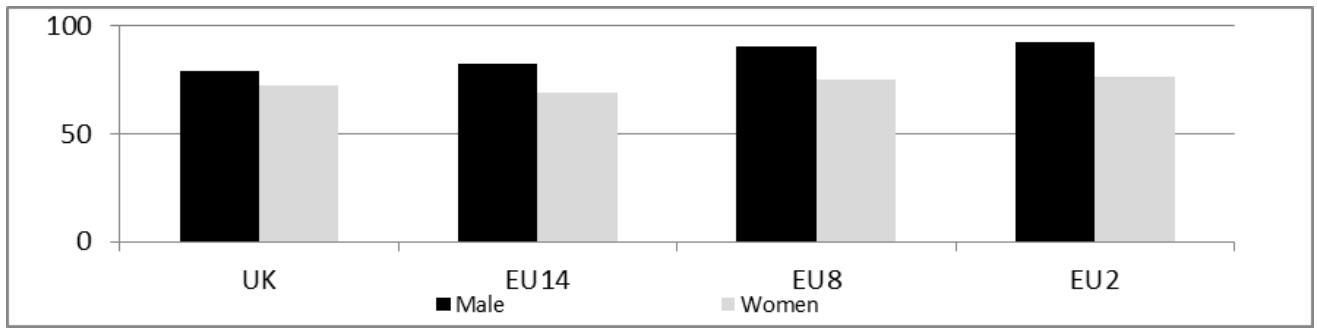

Fig. 3. Employment rate by country of birth, 2018.

Source: Office for National Statistics (GB)

UK-born men's wages have exceeded those of male European migrants. This is to be a result of the higher share of EU8 and E2 migrants who, being employed in lower skilled 
occupations, have been earning a lower hourly wage. Although characterised by very high employment rates, workers from the EU2 and EU8 countries earn the lowest wages among groups considered, because workers born in EU2 and EU8 are poorly paid. On the other hand, workers from EU14 have higher hourly wages than UK-born men. The trends are similar for female migrants, see figure 4 .

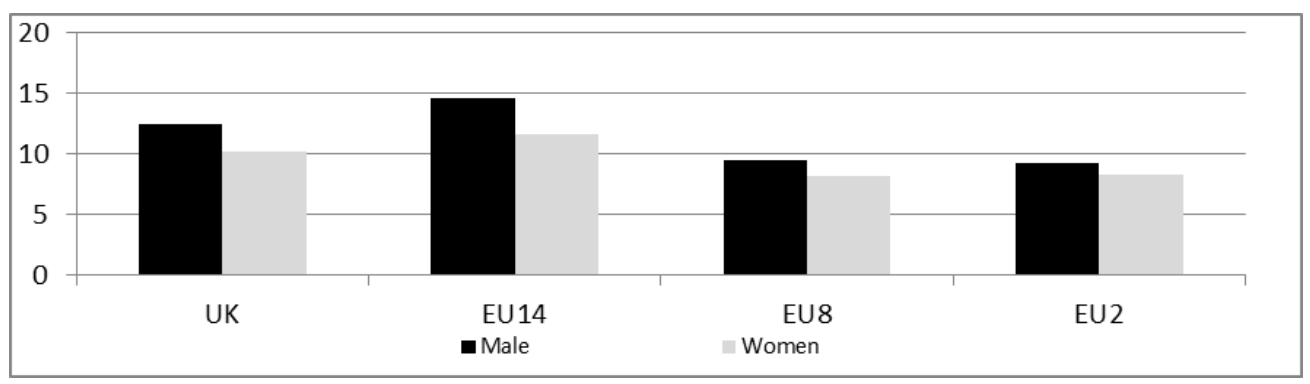

Fig. 4. Median hourly wage (£) by country of birth, 2018

Source: Office for National Statistics (GB)

Even when the averages reported above may mask significant variations in employment rates and in hour wages, it is evident that Eastern European migrants are mostly part of the secondary labour market where created workplaces have worse working conditions and poorer wages [10]. EU8 and EU2 born workers are overrepresented in elementary occupations, such as cleaners, kitchen and catering assistants, building workers, carpenters and chefs and less part of that workers were employed in skilled jobs [11]. There can sometimes be a mismatch between an individual's educational attainment and the skill level required for his or her job in the UK. Specific groups of recent migrants from the EU8 and EU2 countries are known to be frequently employed in jobs that do not correspond with their education and skills [12].

Workers born in EU8 and EU2 are poorly paid and their jobs are often called 3D jobs where they do dirty, difficult and dangerous work and in that context have been raised questions on modern slavery ${ }^{\dagger}$. Some Pols, Czechs or Slovakian people are brought to the UK with the offer of employment and, after arrival, gang leaders seize them documents, opening multiple bank and utility accounts in their names - but refuse to hand over access to the accounts or bank cards. Workers do 3D work and are abused and controlled by threats of harm to their families at home $[13,14]$. Some of that workers do work in the farming sector harvesting grains or root vegetables, tending livestock or fruit picking, some workers do work in building sector or in manufacturing and are being exploited every day in the UK*. Modern slavery workers are invisible people, but very visible are Roma migrants born in the Czech Republic along with Roma migrants born in Slovakia living in the UK mainly gathered in socially excluded areas living on social benefits receiving them without any work [15]. Well - known socially excluded areas are in county Kent [16].

\footnotetext{
${ }^{\dagger}$ Modern slavery is a crime where the most vulnerable men, women and children are abused for criminal profit, with many victims forced to live and work in squalid conditions for little or no money. They are controlled with threats and abuse and have no means of escape. They are considered to be invisible.

$\$$ Women from across eastern Europe are lured to the UK by fake migration services who betray them fall into a dark spiral of sexual exploitation and forced, unpaid prostitution, unable to escape.
} 


\section{Conclusion}

The number of people migrating to the UK has been greater than the number emigrating since 1994. However, for much of the twentieth century, the numbers migrating to and from the UK were roughly in balance, and from the 1960s to the early 1990 s the number of emigrants was often greater than the number of immigrants. Over the last twenty five years, both immigration and emigration have increased to historically high levels, with immigration exceeding emigration by more than 100,000 in every year since 1998. In 2018, the largest group of migrants in the UK $(832,000)$ was born in Poland, followed by migrants from India and Pakistan. A large group of migrants was also born in Romania $(392,000)$, ranked fourth. Relatively small is the group of migrants from the Czech Republic $(45,000)$, which is on the $47 \mathrm{rd}$ place. Strong incentives for migration from East European countries include much higher wages in the UK relative to the countries of Eastern Europe, the pull effect of people already are in the UK and political turbulence in Eastern Europe.

The migrants coming from Eastern Europe and their economic status has become a major topic in the UK, as this issue was one of the main arguments for the leaving the European Union in the UK's Referendum held in 2016. The negative view on migrants from Eastern Europe relies on the fact that these migrants are a major burden for the British social and healthcare system. However, there is a little evidence available for debate about that issues. It seams that migrants pay more in tax than they claim in benefits, because their employment rate is very high. But this ignores the extent to which tax has also to be spent on services consumed by the migrant population including health, and education and additional infrastructure required. These elements should be included into the overall fiscal balance. These calculations may vary by breaking down revenues between direct and indirect taxes, and identifying expenditure under the broad headings of old-age benefits, working-age benefits, health and education. Therefore, there is no clear answer to that key issue.

Looking ahead, the attractiveness of the UK for potential migrants from the East European countries has been reduced by uncertainty stemming from the Brexit process, by the risk of a further devaluation of sterling and by the possibility of a period of lower growth. On the other hand, there will continue to be a large wage disparity between the UK and the East European countries.

As regards to the Poland there has been a significant reduction in net migration in the year 2018 which may reflect improving economic conditions in Poland and reduced exchange rate. Nevertheless, the large Polish diaspora already in the UK will continue to act as a pull factor. Romania is in a different proposition. Economic and political conditions in these country have remained poor. It is therefore likely that there will continue to be a significant inflow. Regarding to the Czech Republic, migrants stocks in UK is not very significant and it seems to be clear that uncertainty arising from Brexit will be a push factor especially for the Czech Roma population as access to social benefits will probably be tightened after the UK leaves the EU.

The paper resulted from the grant - financial support of the Internal grant agency of the University of Economics, Prague IGS F5/12/2018

\section{References}

1. Migration Observatory, Migrants in the UK Labour Market: An Overview, Release date: 15 July 2019, (2019) [online]. [cit.2019-8-10]. Available: https://migrationobservatory.ox.ac.uk/resources/briefings/migrants-in-the-uk-labourmarket-an-overview 
2. A. M. Petersen, M. Puliga, High-skilled labour mobility in Europe before and after the 2004 enlargement, Journal of the Royal society interface, 14, 9 (2017)

3. J. Felbo-Kolding, J. Leschke, T.F. Spreckelsen, A division of labour? Labour market segmentation by region of origin: the case of intra-EU migrants in the UK, Germany and Denmark, Journal of ethnic and migration studies 45, 2820-2843 (2019)

4. United Nations, Department of Economic and Social Affairs, Population Division: The 2019 Revision of World Population Prospects (2019) [online]. [cit.2018-8-1]. Available: https://population.un.org/wpp/

5. Office for National Statistics (GB), Dataset: Population of the UK by country of birth and nationality, Release date: 24 May 2019, (2019) [online]. [cit.2019-8-26]. Available:

https://www.ons.gov.uk/peoplepopulationandcommunity/populationandmigration/inter nationalmigration/datasets/populationoftheunitedkingdombycountryofbirthandnationali ty

6. Office for National Statistics (GB), Migration Statistics Quarterly Report. Statistical bulletin released quarterly in 2011 - 2019. (2019), [online]. [cit.2018-7-11]. Available: https://www.ons.gov.uk/search?q=migration

7. Office for National Statistics, Labour Force Survey, (2019) [online]. [cit.2019-8-10]. Available: https://www.ons.gov.uk/search?q=Labor+Force+Survay

8. M. J. Piore, Birds of passage: Migrant labour and industrial societies. London; New York, Melbourne: Cambridge University Press. (1979).

9. A. Strockmeijer, P. de Beer, J. Dagevos, Should I stay or should I go? What we can learn from working patterns of Central and Eastern European labour migrants about the nature of present-day migration, Journal of ethnic and migration studies, 45, 24302446 (2019)

10. L. McDowell, Old and New European Economic Migrants: Whiteness and Managed Migration Policies, Journal of ethnic and migration studies, 35, 19-36, (2009)

11. R. Johnston, N. Khattab, D. Manley, East versus West? Over-qualification and Earnings among the UK's European Migrants, Journal of ethnic and migration studies 41, 196-218 (2015)

12. D. McCollum, A. Findlay, "Flexible' Workers for "Flexible' Jobs? The Labour Market Function of A8 Migrant Labour in the UK Work employment and society, 29, 427443, (2015)

13. Wadsworth, The UK Labour Market and Immigration. National Institute Economic Review 213, R35-R42. (2010)

14. N. Khattab, J. Fox, East-European immigrants responding to the recession in Britain: is there a trade-off between unemployment and over-qualification? 42, 1774-1789 (2016)

15. CH. O'Hanlon, The European Struggle to Educate and Include Roma People: A Critique of Differences in Policy and Practice in Western and Eastern EU Countries, Social exclusion, 4, 1-10 (2016)

16. V. Nagy, The Janus face of precarity - Securitisation of Roma mobility in the UK, Local economy, 33, 127-146, (2018) 